\title{
Pozycja i znaczenie partii wywodzących się z systemu niedemokratycznego na scenie partyjnej w Polsce, Czechach, Słowacji i na Węgrzech po 1989 r.
}

Dartie polityczne wywodzące się z systemu niedemokratycznego stały 1 się ważnymi elementami systemów partyjnych w Polsce, Czechach, Słowacji i na Węgrzech, uczestnicząc czynnie w procesie transformacji. W artykule chciałbym określić pozycję i ważność tych ugrupowań dla sceny partyjnej odpowiednio Polski, Czech, Słowacji i Węgier, określić profile ideologiczne tych partii, a wreszcie odpowiedzieć na pytanie jak ugrupowania te zaadaptowały się do nowego demokratycznego porządku, dlaczego niektóre z nich do dnia dzisiejszego odgrywają kluczową rolę w polityce, inne zaś znajdują się na marginesie życia politycznego. W kręgu mojego zainteresowania pozostają partie spadkobierczynie ugrupowań - partii hegemonicznych, do których przed rokiem 1989 należała pełnia władzy. Są to odpowiednio - Sojusz Lewicy Demokratycznej (SLD) w Polsce, Komunistyczna Partia Czech i Moraw (KSCM) w Czechach, Partia Demokratycznej Lewicy (SDL') na Słowacji i Węgierska Partia Socjalistyczna (MSZP).

Analizując znaczenie wspomnianych partii do wyznaczenia ich relewancji można posłużyć się dwoma wzorami zaproponowanymi przez Antoszewskiego i Herbuta. Pierwszym krokiem jest ustalenie zakresu partycypacji poszczególnych ugrupowań w kolejnych rządach.

Indeks partycypacji wyrażamy wzorem:

$$
I p=g p / G
$$

gdzie: $g p$ - liczba gabinetów, w których uczestniczyła dana partia;

$G$ - suma gabinetów w badanym okresie.

Drugim, określenie zakresu odpowiedzialności politycznej, mierzonego procentem czasu, w jakim dana partia obsadzała stanowisko 
premiera $^{1}$. Wskaźnik ten pozwala zniwelować niedoskonałości prezentowanego powyżej wymiaru partycypacyjnego. W jego przypadku kluczowej roli nie odgrywa sam fakt uczestniczenia danej partii w gabinecie, ale obsada przez nią stanowiska premiera, co dowodzi jej odpowiedzialności za kierowanie polityką państwa.

\section{Zakres odpowiedzialności politycznej wyrażamy wzorem:}

$$
\text { Iop }=p / P
$$

gdzie: $p$ - liczba miesięcy, w których dana partia obsadzała stanowisko premiera;

$P$ - liczba miesięcy $\mathrm{w}$ badanym okresie.

Przy wykorzystaniu dwóch wspomnianych wzorów poczyniono obliczenia dla każdego z czterech krajów, uwzględniając kolejne rządy po 1989 r., a kończąc na ostatnich gabinetach, które zakończyły swoją działalność (inaczej mówiąc w obliczeniach nie uwzględniono aktualnie rządzących).

Jest to oczywiście pewne przybliżenie, ze względu na bardzo dynamiczny charakter zmian na scenach partyjnych, zwłaszcza Polski i Słowacji, gdzie bardzo często dochodziło do powstawania nowych partii, ich łączenia się, wchłaniania mniejszych ugrupowań przez większe.

Ze względu na trudności z określeniem przynależności partyjnej, z obliczeń wykluczony został rząd T. Mazowieckiego. Do obliczeń włączony został natomiast gabinet Jana Krzysztofa Bieleckiego, którego zaplecze stanowił Obywatelski Klub Parlamentarny. Jednak w tym okresie można było już wyróżnić pewne frakcje w ramach OKP, które później przekształciły się w partie polityczne. Dlatego ugrupowaniom postsolidarnościowym tworzącym i działającym wcześniej w ramach OKP „zaliczony” został udział w rządzie Bieleckiego. Spośród rządów, które można poddać analizie w Czechach, należy wyłączyć gabinety P. Pitharta i J. Tosovskiego. Pierwszy z nich, podobnie jak w Polsce gabinet Tadeusza Mazowieckiego, powstał w oparciu o szeroką koalicję sił niepodległościowych (Forum Obywatelskie), gdzie poszczególne ugrupowania polityczne dopiero się kształtowały. Dlatego trudno określić znaczenie i wpływ powstałych później partii politycznych na politykę tego rządu. Podobna sytuacja występuje z powołanym przejściowo rządem fachowców J. To-

1 A. Antoszewski, R. Herbut, W. Jednaka, Partie $i$ systemy partyjne $w$ Polsce. Pierwsza faza przejścia ku demokracji, Wrocław 1993, s. 72-73. 
sovskiego, który oprócz bezpartyjnych fachowców, tworzyli politycy niektórych partii, natomiast nie został on oficjalnie poparty przez żadne z ugrupowań. Spośród badanych rządów na Słowacji, pominięte zostaną dwa pierwsze. Sa to gabinety tworzone lub popierane przez VPN (Społeczeństwo Przeciw Przemocy), masowy ruch społeczny, z którego dopiero później zaczęły wyodrębniać się partie polityczne. W obliczeniach na Węgrzech rząd J. Antalla i jego następcy P. Borossa, ze względu na „niepolityczną" przyczynę zmiany szefa rządu (śmierć Antalla), został potraktowany łącznie.

W obliczeniach również jako jedna partia występuje Unia Wolności (wcześniej Unia Demokratyczna), a także szeroko rozumiany nurt „Solidarnościowy”, reprezentowany wcześniej przez samą, „Solidarność” później zaś przez AWS, łącznie potraktowane zostało również PC i PiS. Problem mamy również z rządem M. Belki, który w pewnym momencie uniezależnił się od SLD. Kwestią dyskusyjną jest również klasyfikacja partii, które oficjalnie nie wchodziły w skład koalicji rządowej na Słowacji, jednak czynnie ją popierały, np. SNS i SDL'w drugim rządzie Meciara. W moich obliczeniach partie te będą traktowane jako oficjalnie tworzące koalicję rządową.

Indeks partycypacji - Polska:

$\operatorname{Ip}(\mathrm{UW} / \mathrm{UD})=3 / 12=0,25$

Ip $(\mathrm{SLD} / \mathrm{SDRP})=5 / 12=0,42$

Ip $($,Solidarność"/AWS $)=4 / 12=0,33$

Ip $(\mathrm{PSL})=5 / 12=0,42$

Ip $($ KLD bez UW $)=2 / 12=0,16$

Ip $(\mathrm{ZChN})=3 / 12=0,25$

Ip $(\mathrm{POC} / \mathrm{PC} / \mathrm{PiS})=4 / 12=0,33$

Źródło: Obliczenia własne.

Zakres odpowiedzialności politycznej - Polska - całkowita ilość miesięcy 203 od roku 1991, momentu powstania gabinetu J. K. Kieleckiego:

Iop $(\mathrm{UW} / \mathrm{UD})=15 / 203=0,07$

Iop $(\mathrm{SLD} / \mathrm{SDRP})=77 / 203=0,38$

Iop $($,Solidarność $/$ AWS $)=48 / 203=0,24$

Iop $(\mathrm{PSL})=14 / 203=0,06$

Iop $(\mathrm{KLD}$ bez UW $)=11 / 203=0,05$

Iop $(\mathrm{POC} / \mathrm{PC} / \mathrm{PiS})=32 / 203=0,15$

Źródło: Obliczenia własne. 
Dane te można obrazowo przedstawić na wykresie, gdzie dwie osie zmiennych zostaną nazwane odpowiednio: indeks partycypacji i zakres odpowiedzialności politycznej (w podobny sposób zostaną one zilustrowane dla pozostałych krajów).

Wykres 1. Indeks partycypacji i zakres odpowiedzialności politycznej wybranych partii politycznych w Polsce w latach 1991-2007

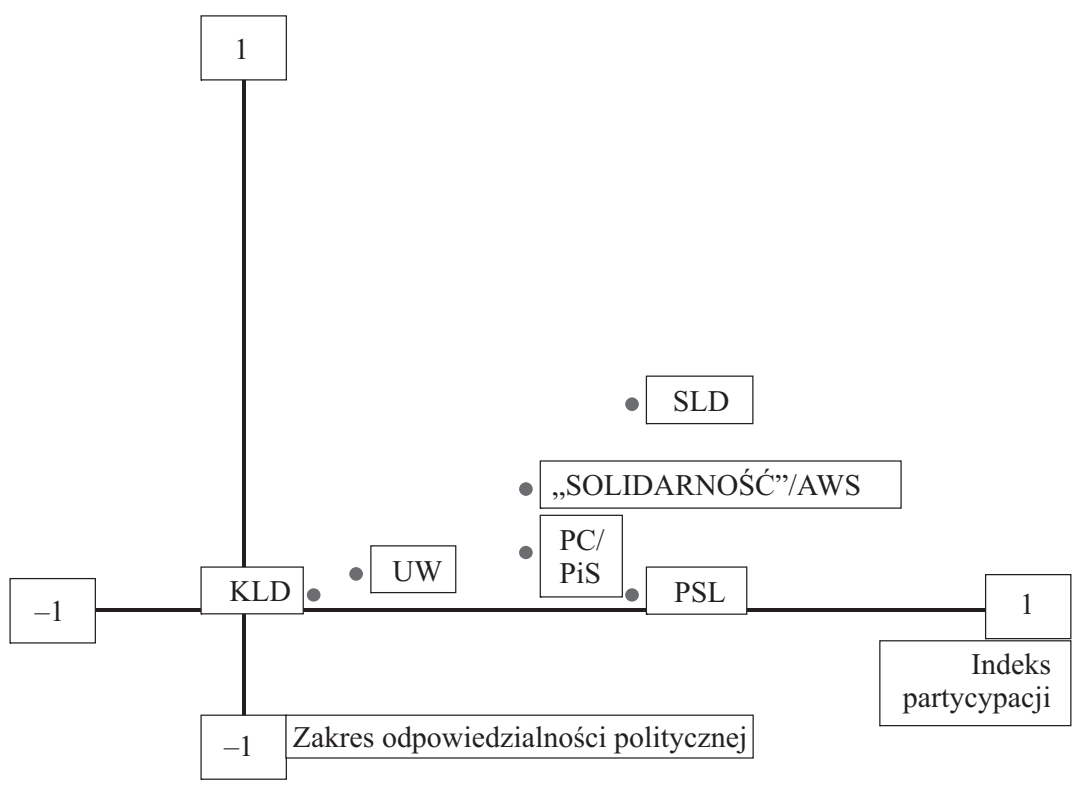

Źródło: Opracowanie własne.

Jak widać, partią, która miała największy wpływ na polską politykę w badanym okresie, zarówno jeśli chodzi o indeks partycypacji, jak i zakres odpowiedzialności politycznej, jest właśnie ugrupowanie wywodzące się z minionego systemu - SLD.

Indeks partycypacji - Czechy:

Ip $(\mathrm{ODS})=3 / 7=0,42$ (jeśli uwzględniony zostałby również gabinet M. Zemana działający za przyzwoleniem ODS, wskaźnik ten byłby wyższy) Ip $($ KDU-CSL $)=6 / 7=0,85$

Ip $(\mathrm{ODA})=2 / 7=0,28$

Ip $(\mathrm{CSSD})=4 / 7=0,57$

Źródło: Obliczenia własne. 
Zakres odpowiedzialności politycznej - Czechy - całkowita ilość miesięcy 102 od roku 1992, momentu powstania gabinetu V. Klausa:

Iop $(\mathrm{ODS})=98 / 202=0,48$

Iop $(\mathrm{CSSD})=96 / 202=0,47$

Źródlo: Obliczenia własne.

Wykres 2. Indeks partycypacji i zakres odpowiedzialności politycznej wybranych partii politycznych w Czechach w latach 1992-2009

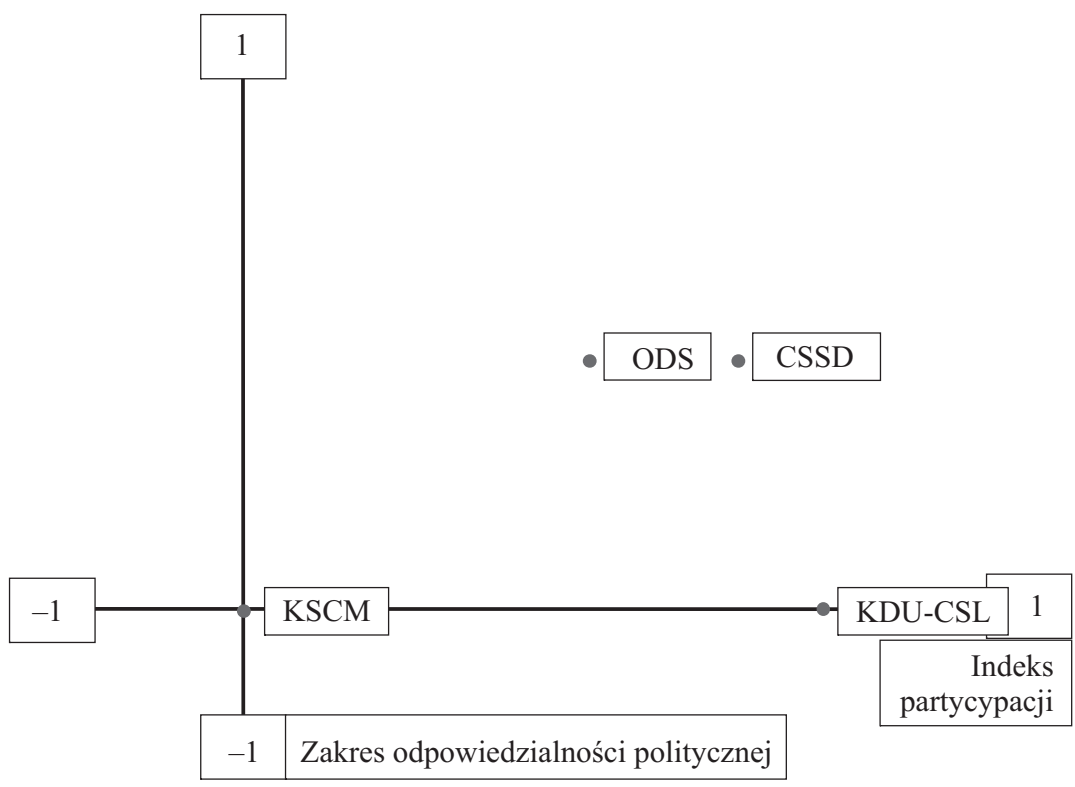

Źródło: Opracowanie własne.

Przedstawione wyżej wyniki jasno pokazują, iż partią, która miała największy wpływ na sytuację polityczną w Czechach w omawianym okresie jest CSSD, wyróżniająca się zarówno bardzo wysokim wskaźnikiem indeksu partycypacji, jak i zakresu odpowiedzialności politycznej. Na drugim miejscu znajduje się ODS, jedyna obok CSSD partia, której przedstawiciel piastował urząd premiera (w Polsce takich partii było aż sześć). Kolejną partią w rankingu ważności jest KDU-CSL - partia o bardzo wysokim wskaźniku partycypacji, która jednak nigdy nie desygnowała premiera. Na marginesie tego zestawienia pozostaje zaś były hegemon - KSCM. 
Indeks partycypacji - Słowacja:

Ip $(\mathrm{HZDS})=2 / 5=0,4$

$I p(\mathrm{SNS})=2 / 5=0,4$

Ip $\left(\mathrm{SDL}^{\prime}\right)=3 / 5=0,6$

Ip $(\mathrm{DU})=2 / 5=0,4$

Ip (KDH) $2 / 5=0,4$

Ip $\mathrm{SDKU} 2 / 5=0,4$

Źródło: Obliczenia własne.

Zakres odpowiedzialności politycznej - Słowacja - całkowita ilość miesięcy 169 od roku 1992, momentu powstania drugiego rządu V. Meciara:

Iop $(\mathrm{HZDS})=67 / 169=0,39$

Iop $(\mathrm{DU})=9 / 124=0,05$

Iop $(\mathrm{SDKU})=93 / 169=0,55$

Źródlo: Obliczenia własne.

Wykres 3. Indeks partycypacji i zakres odpowiedzialności politycznej wybranych partii politycznych na Slowacji w latach 1992-2006

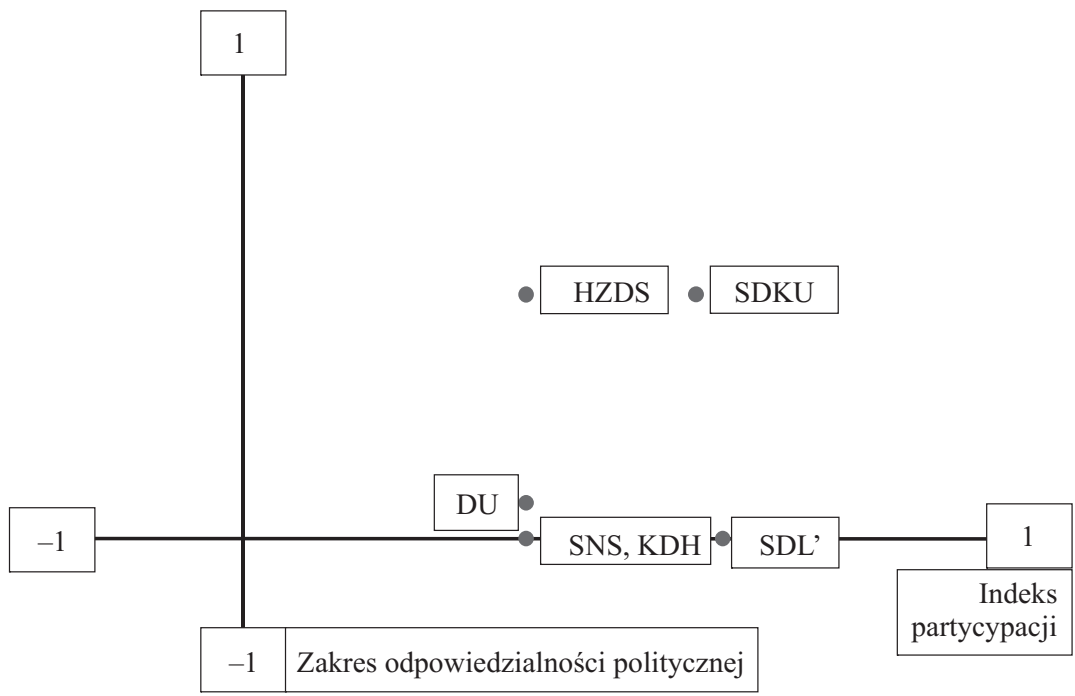

Źródło: Opracowanie własne.

Jak pokazują powyższe obliczenia i zamieszczony wykres, na słowackiej scenie politycznej partią dominująca jest Słowacka Koalicja Demokratyczna, tuż za nią plasuje się HZDS - partia V. Meciara. Ugrupowanie interesujące mnie 
SDL' może pochwalić się najwyższym w badanym okresie wskaźnikiem partycypacji - partia ta nie piastowała jednak nigdy stanowiska premiera.

Indeks partycypacji - Węgry:

Ip $(\mathrm{MDF})=2 / 5=0,4$

Ip $(\mathrm{FKgP})=2 / 5=0,4$

Ip $(\mathrm{MSZP})=3 / 5=0,6$

Ip $(\mathrm{SZDSZ})=3 / 5=0,6$

Ip (FIDESZ-MPP) $1 / 5=0,2$

Ip $(\mathrm{KDN}) 1 / 5=0,2$

Źródło: Obliczenia własne.

Zakres odpowiedzialności politycznej - Węgry - całkowita ilość miesięcy 225 od roku 1990, momentu powstania gabinetu J. Antalla:

Iop $(\mathrm{MDF})=48 / 225=0,21$

Iop $(\mathrm{MSZP})=128 / 225=0,56$

Iop $($ FIDESZ-MPP $)=45 / 225=0,2$

Źródło: Obliczenia własne.

Wykres 4. Indeks partycypacji i zakres odpowiedzialności politycznej wybranych partii politycznych na Węgrzech w latach 1990-2009

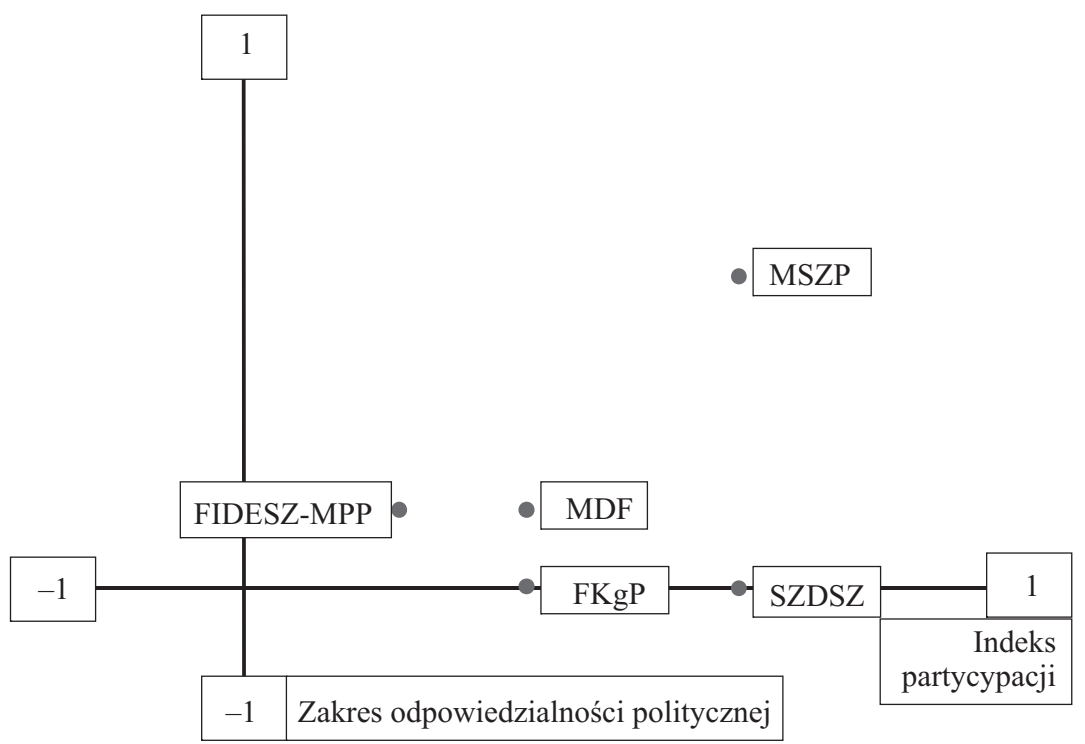

Źródło: Opracowanie własne. 
Jak wskazują powyższe obliczenia, w przypadku Węgier zdecydowanym liderem jest spadkobierczyni partii komunistycznej - Węgierska Partia Socjalistyczna, obok tej partii tylko dwa inne ugrupowania miały $\mathrm{w}$ swych szeregach premiera $\mathrm{tj}$. Węgierskie Forum Demokratyczne i Związek Młodych Demokratów.

Na kolejnym wykresie zaprezentowano również wartości indeksu partycypacji i odpowiedzialności politycznej tylko dla czterech interesujących mnie partii.

Wykres 5. Indeks partycypacji i zakres odpowiedzialności politycznej wybranych partii politycznych w latach 1990-2009

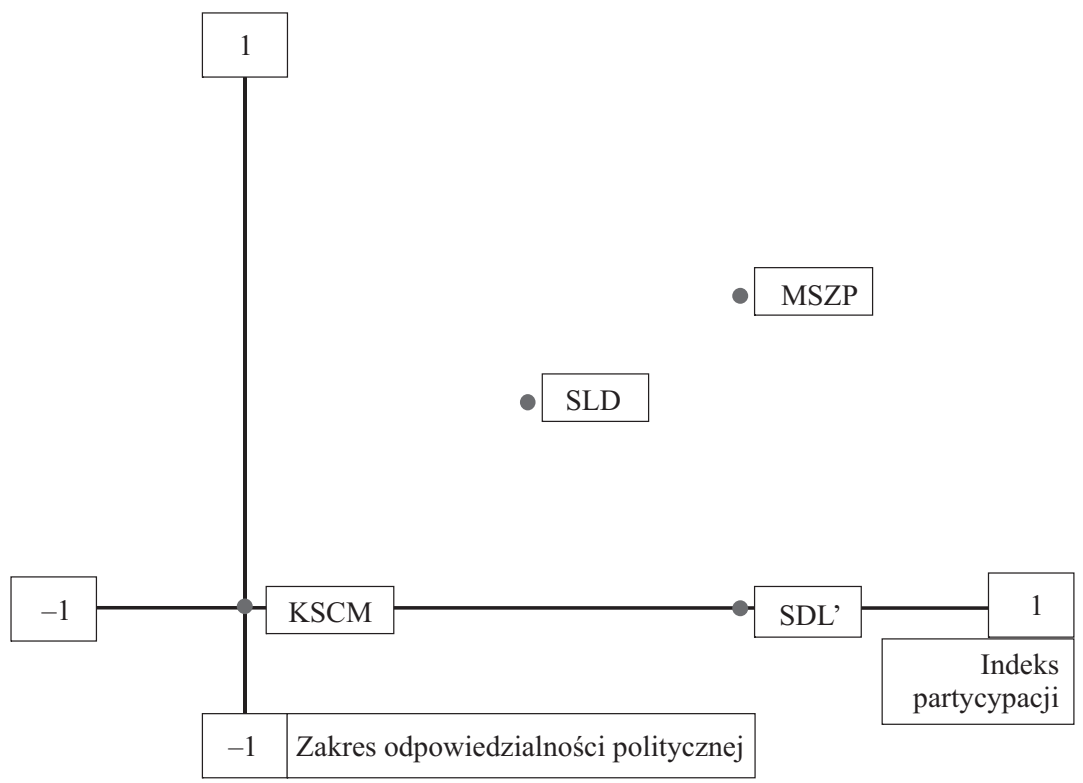

Źródło: Opracowanie własne.

Powyższa analiza wskazuje na bardzo silną pozycję ugrupowań wywodzących się z minionego systemu (dwa z nich okazały się najsilniejsze w swoich krajach SLD i MSZP, kolejne SDL', chociaż nie desygnowało premiera mogło pochwalić się bardzo wysokim wskaźnikiem partycypacji, outsiderem w tym zestawieniu pozostaje jedynie Komunistyczna Partia Czech i Moraw. Jednak, aby obraz ten był pełniejszy należy się kilka słów komentarza i krótka charakterystyka każdej z partii, które pokażą, iż na dzień dzisiejszy pozycja i znaczenie poszczególnych partii jest zupełnie inne. 


\section{KSCM}

Komunistyczna Partia Czech i Moraw jest bezpośrednio związana z Komunistyczną Partią Czechosłowacji. Partia ta, w przeciwieństwie do partii rządzących przed 1989 r. w Polsce i na Węgrzech nie rozwiązała się i nie zmieniła swojej nazwy (wyodrębniła się tylko część czeska i słowacka). KSCM istnieje nieprzerwanie od 1920 r. i w odróżnieniu od pozostałych partii nie przeszła żadnej metamorfozy ani pod względem nazwy, ani pod względem struktury.

Mimo nieustannego odwoływania się do komunistycznej przeszłości, członkowie KSCM dalej tytułują się „towarzyszami” i trzymują kontakty m.in. z rządzącymi komunistami na Kubie i w Korei Północnej, a wrogiem dalej są NATO i kapitalizm. Przez ostatnich dwadzieścia lat Komunistyczna Partia Czech i Moraw była trzecią siłą polityczną w Republice Czeskiej, uzyskując w kolejnych wyborach poparcie na poziomie od $10,33 \%$ do $20,26 \%$ głosów. Ten najwyższy, ponad 20\% wynik komuniści uzyskali w wyborach do Europarlamentu w 2004 r. (więcej głosów dostała tylko CSSD). W 1999 r. Partia Komunistyczna co prawda tylko w sondażach, ale znajdowała się na czele rankingu popularności partii politycznych. Wyniki wyborcze komunistów w Czechach są ewenementem w Europie Środkowej. Tym bardziej, gdy osiaga je ugrupowanie idące do wyborów pod hasłem: „Socjalizm szansą na przyszłość”, a tak było w 1996 r.

W Czechach już niejednokrotnie rozważano możliwość koalicji dwóch ugrupowań zasiadających po lewej stronie parlamentu, ale socjaldemokraci nigdy na jawny sojusz z komunistami się nie zdecydowali - obowiązuje ich uchwała z 1995 r., kiedy to na swym zjeździe zadeklarowali, że z komunistami nie będą współpracować (interpretowane jest to jako współpraca na płaszczyźnie centralnej; do współpracy w samorządach już się nie odnosi). Głównym powodem jest obawa przed utratą społecznego poparcia. Choć CSSD wykluczyła możliwość szerszej współpracy z komunistami, pod koniec 2008 r. koalicje CSSD z Komunistyczną Partią Czech i Moraw zapewniły dawnym członkom KSCM najwyższe stanowiska na szczeblu lokalnym. Jak pisze A. Krawczyk: „Partia komunistyczna stanowi języczek u wagi w sporze między dwiema głównymi siłami politycznymi - Partią Socjaldemokratyczną i Partią Obywatelsko-Demokratyczną. Prawica bez przerwy ostrzega socjaldemokratów, że każda próba koalicji z komunistami oznaczałaby ,zdradę demokracji. Tym samym zapędza do kąta socjaldemokratów, którym brakuje kilku-kilkunastu 
głosów do stworzenia większości parlamentarnej”’2. Na szczeblu lokalnym prawicowa ODS wielokrotnie wchodzi w mniej lub bardziej formalne koalicje z komunistami, by odsunąć od władzy socjaldemokratów.

Jednocześnie już kilka razy podejmowano w Czechach próby delegalizacji Partii Komunistycznej, domagając się, aby KSCM zrezygnowała z odwoływania się do komunistycznego totalitaryzmu - jego propagowanie jest w Czechach konstytucyjnie zabronione. Politycy komunistyczni wielokrotnie wykluczali taką możliwość. Do przeforsowania delegalizacji potrzebne jest wsparcie dwóch największych czeskich ugrupowań. I o ile Obywatelska Partia Demokratyczna (ODS) wspierała tego typu pomysły, o tyle Czeska Partia Socjaldemokratyczna nigdy nie zdecydowała się na taki krok. Może to wynikać również z faktu, iż KSCM liczy 90 tys. członków (w porównaniu z największymi partiami polskimi to wynik imponujący).

\section{SDL'}

Partią, która zajmowała ważne miejsce na słowackiej scenie partyjnej jest Partia Demokratycznej Lewicy. Partia ta powstała w wyniku przekształcenia słowackiej części Komunistycznej Partii Czechosłowacji, na powyborczym zjeździe w październiku $1990 \mathrm{r}$. W wyniku podziału wśród komunistów, reformatorsko nastawieni działacze zdecydowali się na powołanie Partii Demokratycznej Lewicy. Zaowocowało to wkrótce zerwaniem współpracy federacyjnej z Komunistyczną Partią Czech i Moraw i zbliżeniem się do profilu socjaldemokratycznego. W programie SDL' znalazły się zapisy o potrzebie ochrony najuboższych przy jednoczesnej akceptacji reguł wolnego rynku.

Program wyborczy SDL' z jednej strony opowiadał się za stłumieniem państwowego paternalizmu, z drugiej jednak zakładał możliwość interweniowania państwa w tych dziedzinach, w których jest to nieuniknione. Dobrym przykładem był choćby zamiar zwiększania konkurencyjności. SDL' nie wierzyła, że przedsiębiorstwa same dadzą sobie radę i dlatego zakładała uczestnictwo państwa w tym procesie. Partia ta programowo ewoluowała w stronę centrum, np. początkowo wypowiadała się zdecydowanie przeciwko wstapieniu Słowacji do NATO, by później zmienić zdanie w tej

2 A. Krawczyk, Czechy: Komunizm wiecznie żywy, „Gazeta Wyborcza” z dnia 5 lipca 2007 r. 
kwestii - cały czas nie była to jednak pełna akceptacja dla programu socjaldemokratycznego. Był to jednak program jakże różny od proponowanego przez KSCM w Czechach. Ten brak wyboru jednej drogi programowej skutkował stałym spadkiem poparcia dla SDL'.

Kryzys w partii pogłębiło również wycofanie przez nią poparcia dla rekomendowanej przez lewicę i cenionej minister finansów Brigity Schmoegnerovej. Jak pisze T. Grabiński: ,padła ona ofiarą walki własnej partii o przetrwanie. Wśród polityków SDL' powstało przekonanie, że to ona jest odpowiedzialna za spadek popularności partii na kilka miesięcy przed wyborami 2002 r. Jak prawie każdy minister finansów komplementowana przez fachowców Schmoegnerova nie była ulubienicą opinii publicznej. Jej koledzy wykorzystali przeciwko niej ostatnie posunięcie - nałożenie na każdego pracującego Słowaka obowiązku złożenia zeznania majątkowego, co miało pomóc w walce $\mathrm{z}$ nieopodatkowanymi dochodami”’3. Wycofanie rekomendacji dla Schmoegnerovej było elementem walki nowych, bardziej twardogłowych przywódców postkomunistów o przetrwanie partii, która balansowała na granicy progu wyborczego. Większość wyborców głosujących na SDL’ w 1998 r. odeszła do założonego przez byłego wiceszefa SDL' Roberta Fico ugrupowania Smer (Kierunek).

Odwołanie minister Schmoegnerovej nie zapobiegło katastrofie, a wręcz ją pogłębiło. W wyborach 2002 r. SDL' uzyskała tylko 1,4\% poparcia, podczas gdy do tej pory marginalna i ortodoksyjna Komunistyczna Partia Słowacji otrzymała ponad 6\% głosów i weszła do parlamentu. Po klęsce wyborczej Partia Demokratycznej Lewicy przestała istnieć i została wchłonięta przez wspomniany Smer R. Fico. Jej założyciel zadeklarował chęć poszukiwania nowego sposobu uprawiania polityki, znalezienia trzeciej drogi pomiędzy kapitalizmem a socjalizmem. Smer akceptując zasady gospodarki wolnorynkowej, podkreślał jednocześnie potrzebę zagwarantowania zabezpieczeń socjalnych ze strony państwa. R. Fico jest dzisiaj premierem Słowacji.

\section{MSZP}

Jeszcze do niedawna prawdziwym hegemonem na węgierskiej scenie partyjnej była Węgierska Partia Socjalistyczna. Ugrupowanie to powstało

3 T. Grabiński, Albo ona, albo my, „Gazeta Wyborcza” z dnia 24 stycznia 2002 r. 
w październiku 1989 r. z inicjatywy twórców węierskiej pierestrojki, członków Węgierskiej Socjalistycznej Partii Robotniczej. Jej korzenie sięgają Węgierskiej Socjalistycznej Partii Robotniczej, jednak wśród jej założycieli znalazło się tylko 10\% członków dawnego ugrupowania. Od początku opowiadała się za wolnym rynkiem, kładąc jednocześnie duży nacisk na opiekę socjalną. Określając się mianem „narodowego środka”, starała przeistoczyć się w partię socjaldemokratyczną w stylu zachodnio-europejskim. Węgierski historyk C. G. Kiss scharakteryzował ją następująco: „Jej skład jest niezwykle zróżnicowany: od działaczy polityczno-gospodarczych wywodzących się z dawnej nomenklatury, którzy po nagłej transformacji występują dziś jako zagorzali zwolennicy thatcheryzmu, aż po ludzi z ruchu związkowego. Jest to partia eklektyczna, w której mieszczą się przedstawiciele młodszego pokolenia partyjno-rządowej biurokracji z czasów Kadara, wczorajsi zwolennicy komunistycznych reform i była kierownicza kadra przedsiębiorstw państwowych"4. MSZP, podobnie jak SLD w Polsce starała się skupić wszystkie nurty lewicy, próbuje więc balansować między rozdawnictwem - kontynuując kadaryzm - oraz reformami. Na MSZP głosuje zarówno nowoczesna część społeczeństwa, grupy wspierające reformy i kurs na Zachód, jak i zwolennicy kadaryzmu, którzy stanowią większość jej wyborców.

Z punktu widzenia ekonomii, socjaliści prezentują poglądy centrowe, opowiadając się za wolnym rynkiem, lecz stosując do tego celu retorykę lewicową. Mimo tych miejscami ostrożnych zapowiedzi programowych, to właśnie rząd G. Horna w latach 1994-1998, wprowadził najbardziej liberalne reformy gospodarcze w historii Węgier (pakiet L. Bokrosa), ratując jednocześnie, przynajmniej na jakiś czas, budżet tego państwa przed bankructwem. Bardzo trafnie skomentował to J. Kornai: „Na Węgrzech nastąpiła obecnie osobliwa zamiana ról. Mówiąc w pewnym uproszczeniu, Partia Socjalistyczna, wygrawszy wybory dzięki uwydatnieniu swojej wrażliwości społecznej, realizuje obecnie program „thatcherowski”. W tym czasie politycy określający siebie jako konserwatyści na prawo od centrum posługują się argumentami socjaldemokratycznymi, a więc postulują rozrost państwa opiekuńczego i zaspokojenie żądań płacowych pracowników"5. Ponieważ ta liberalizacja gospodarcza zakończyła się klęską wyborczą i przejęciem władzy w 1998 r. przez opozycyjny Fidesz,

4 C. G. Kiss, Quo vadis Hungaria, ,Rzeczpospolita” z dnia 16 maja 1995 r.

5 J. Kornai, Stabilizacja i wzrost w procesie transformacji. Przypadek gospodarki węierskiej, Poznań 1998, s. 145. 
w kolejnych wyborach partia skręciła zdecydowanie w lewą stronę. Spora część osób o poglądach lewicowych do dziś uważa, że jesienią 1989 roku transformacja podążyła w niewłaściwą stronę. Jak dodaje J. Kis: „Gdy w 2002 r. lewica wystapiła z programem «transformacji dobrobytu», miała na myśli nie tylko to, że podniesienie płac i emerytur zwiększy jej popularność wśród wyborców. Polityka «transformacji dobrobytu» miała odnowić stary model opieki państwowej, dowodząc tym samym, że nowy porządek może zyskać sympatię poprzez przywrócenie ciągłości z reżimem sprzed 1989 r." ${ }^{\prime 6}$. To zapewniło socjalistom bezprecedensowy sukces wyborczy, doprowadziło jednak kraj na krawędź katastrofy gospodarczej, a sama partia poniosła klęskę w ostatnich wyborach parlamentarnych (klęskę, którą można porównać jedynie z wynikiem lewicy w Polsce w 2005 r.). Przy wysokiej frekwencji prawicowy Fidesz zdobył ponad 50\% głosów, lewica niecałe $20 \%$. We wcześniejszych wyborach począwszy od 1998 r. różnica ta wynosiła maksymalnie 3 pkt. procentowe.

\section{SLD}

Po przegranych wyborach w 2005 r. SLD znalazła się na marginesie życia politycznego w Polsce, a główny konflikt rozgrywa się między dwiema partiami prawicowymi: Prawem i Sprawiedliwością i Platformą Obywatelską. Zmajoryzowały one scenę polityczną i zdominowały dyskurs medialny, sprawnie regulując obieg treści i problemów w nim się pojawiajacych $^{7}$.

Z czego wynika tak głęboki kryzys partii, która jak wykazano wcześniej odgrywała kluczową rolę w życiu politycznym kraju? Po części, z racji niemocy, jaką wykazała lewica solidarnościowa - monopol na politykę socjaldemokratyczną znalazł się w rękach lewicy o PZPR-owskim rodowodzie. Lewica wywodząca się z PZPR od samego początku pozbawiona była fundamentu ideowego i nie miała powodów, by cokolwiek w tym aspekcie zmieniać. To spowodowało, że kryzysy polityczne w postaci korupcji, kompromitacji działaczy, a wreszcie całego ruchu lewicowego, przyniosły z sobą prawdziwą anihilację lewicy ${ }^{8}$. Źródeł tego stanu rzeczy

6 J. Kis, Wegierska wojna domowa, ,Gazeta Wyborcza” z dnia 8 marca 2008 r.

7 K. Czarnecki, Co po kryzysie polskiej lewicy, 25.06.2009, http://www.lewica.pl/?id=19622, 4.04.2010.

8 J. Pinior, Rozpaczliwa agonia lewicy, ,Dziennik” z dnia 27 marca 2009 r. 
jest kilka. Jak pisze P. Szelegieniec: „Lewicowość kojarzona jest ze stalinowskim autorytaryzmem, neoliberalnymi reformami oraz, używając określenia I. Wallersteina, ustanawianiem tzw. «kapitalizmu peryferyjnego», polegającego na «modernizacji niedorozwoju», a nie poprawie położenia biedniejszej części społeczeństwa. Znaczący jest również brak klarownego programu. Doprowadziło to do absurdalnej sytuacji, w której bardzo trudno jest wskazać «cechy szczególne» polskiej lewicy jako takiej”9.

Czy przyczyny tego kryzysu należy się również doszukiwać w odcięciu się od lewicowych ideałów. Tutaj zdania są podzielone wg części autorów, działaczy politycznych i dziennikarzy związanych z lewą stroną sceny politycznej, szansy na reaktywację lewicy należy szukać właśnie w powrocie do lewicowych korzeni ideowych, unikając jednocześnie zbyt daleko idących kompromisów zawieranych z innymi opcjami politycznymi. Te kompromisy powodują, że doszło do zacierania się różnić między tradycyjną prawicą i lewicą. Tego typu opinie charakterystyczne są zwłaszcza dla środowiska „Krytyki politycznej”, wypowiadane wielokrotnie przez Sławomira Sierakowskiego. Jak przekonuje Sierakowski: „Lewica postkomunistyczna, ponieważ chciała uwolnić się od PRL-owskiego garbu, zaczęła ochoczo budować neoliberalny kapitalizm. Ponadto elity III RP nie potrafiły poradzić sobie z prawicowym populizmem, który odniósł krótkotrwałe, ale spektakularne zwycięstwo w 2005 r. Ot i cała tajemnica słabości polskiej lewicy w obliczu kryzysu. I słabości wszystkich lewic, które uwierzyły, że w coraz bogatszym świecie nie stać nas już na państwo opiekuńcze"10.

Inną diagnozę stawiają tu np. Józef Pinior, jedna z najważniejszych postaci lewicy postsolidarnościowej i były premier Leszek Miller. Zdaniem J. Piniora: „Młoda lewica powinna wystrzegać się jałowego radykalizmu. Największym, śmiertelnym błędem, jaki mogłaby popełnić, jest próba negowania instytucji liberalnej demokracji w imię bliżej nieokreślonej «rewolucji». Liczenie na tego rodzaju społeczno-polityczny kataklizm i upadek kapitalizmu jest dziecinadą, która utrwala jedynie prawicową hegemonię w polskiej polityce. Młoda lewica musi wypracować sensowny socjaldemokratyczny program, który pozwoli jej zbudować polityczną alternaty-

9 P. Szelegieniec, Problemy z lewica, 25.03.2010, http://lewica.pl/index.php?id= $21264 \&$ utm_source $=$ feedburner\&utm_medium $=$ feed\&utm_campaign $=$ Feed $\% 3 \mathrm{~A}+$ politykawsieci+\%28Polityka+w+sieci\%29, 7.04.2010.

10 S. Sierakowski w rozmowie z C. Michalskim, Czy lewica zdobędzie władzę?, „Europa” z dnia 11 kwietnia 2009. 
wę dla PO czy PiS"11. Jeszcze dalej w swych pomysłach na uzdrowienie SLD idzie L. Miller, który przekonuje, iż jedynie model blairowski, a więc połączenia neoliberalizmu z polityką socjalną, może okazać się skuteczny. Miller twierdzi, że jest to jedyna słuszna droga dla lewicy. Obstawanie przy postulatach rozbudowanej opieki socjalnej i dużym wpływie państwa na gospodarkę uważa za anachroniczne. Z kolei liberalizm światopoglądowy uznaje za niemożliwy do wprowadzenia bez społecznej akceptacji, o jaką w Polsce trudno.

W efekcie aktualnie w Polsce SLD nie ma własnej propozycji, zestawu haseł i idei, tworzących spójną wizję, które w Polsce przedstawił choćby Jarosław Kaczyński. Pozostaje jej jedynie odpowiadanie na posunięcia prawicy i liberałów.

\section{Uwagi końcowe}

Podsumowując należy zauważyć, iż obecnie ugrupowaniem o największym poparciu społecznym jest KSCM, co jednoznacznie obrazuje kondycję partii wywodzących się z systemu niedemokratycznego. Można wskazać tutaj na dwa modele działania tych partii, z jednej strony trwanie przy programie sprzed 1989 r. (taki model przyjęła KSCM), z drugiej zaś przesunięcia w stronę centrum sceny politycznej (taki scenariusz został zrealizowany przez SLD, SDL' i MSZP). Jak pokazują wyniki ostatnich wyborów i sondaży popularności paradoksalnie większym uznaniem wśród wyborców cieszy się trwanie przy komunizmie. Politycy KSCM wychodzą z założenia, iż komunistyczna przeszłość staje się z biegiem czasu obiektem idealizacji. Ci, którzy nie doświadczyli dawnego ustroju, mają tendencję do utożsamiania komunizmu z antyglobalizmem $\mathrm{i}$ antyamerykanizmem $^{12}$. Ideologia marksistowska nie musi być tożsama $\mathrm{z}$ totalitarnym ustrojem, jakiego zaznała Europa Wschodnia. Komuniści z jednej strony skupiają środowiska ludzi niezadowolonych, zagubionych w nowej rzeczywistości. Z drugiej - to nadal najbardziej radykalna wersja czeskiego nacjonalizmu - antyniemiecka, antyamerykańska. Zarazem są komuniści ,partią protestu”: nigdy nie rządzili, nie byli więc zamieszani w żadną

11 J. Pinior, Rozpaczliwa agonia lewicy, ,Dziennik” z dnia 27 marca 2009 r.

12 M. Galanova, Czeskie fora dyskusyjne a Komunistyczna Partia Czech i Moraw: rozczarowanie i nostalgia za komunistyczna przeszłościa, http://www.cafebabel.pl/article/31834/nostalgia-za-komunistyczna-przeszloscia.html, 3.02.2010. 
z głośnych afer gospodarczych i z wygodnych pozycji od 20 lat krytykują wszystko, co się da. Dziś mogą się prezentować jako krytycy i moralizatorzy $^{13}$. Zdaniem czeskich komentatorów stąd bierze się ich popularność. Jedyny problem to starzenie się elektoratu. Jak piszą autorzy wydanej właśnie książki 1989 - Jesień Narodów, ,rocznie KSCM traci 6-7\% członków, nie zyskując nawet 1\%. Jak wyliczono, codziennie ubywa jej 16 osób, a przeciętny wiek towarzyszy przekroczył 70 lat (ponad dwie trzecie stanowią emeryci)". Przedstawicieli młodszych generacji o poglądach lewicowych skutecznie przyciaga partia socjaldemokratyczna - $\mathrm{CSSD}^{14}$. Mamy więc ugrupowanie o ograniczonym potencjale rozwoju, jednak w chwili obecnej przyciagające dużą grupę wyborców.

Skąd biorą się natomiast tak słabe notowania ugrupowań - SLD, SDL' i MSZP, które zmieniły, czasami radykalnie, swoje programy po $1989 \mathrm{r}$. Wydaje się, że partie wywodzące się z systemu niedemokratycznego, czy to w Polsce, Słowacji, czy na Węgrzech, wyczerpały swój potencjał, jako ugrupowania, które w sferze gospodarczej, w zbyt małym stopniu przesunęły się w stronę centrum sceny politycznej. W celu zapewnienia sobie sukcesu powinny, przynajmniej w sferze gospodarczej, zbliżyć się do wspominanej już wcześniej lewicy w wydaniu blairowskim - tak działa z dużymi sukcesami czeska CSSD. Na inne ugrupowania lewicowe nie ma w tej chwili miejsca. Czy możliwe jest na np. Węgrzech działanie prawdziwie lewicowej lewicy, która wcielałaby w życie postulaty państwa opiekuńczego, w kraju który od lat znajduje się na granicy bankructwa? Czy taka lewica mogła funkcjonować w Polsce w latach 90-tych, gdy konieczne było przeprowadzenie radykalnych reform? Czy taka lewica ma rację bytu dziś, gdy świat zmaga się ze skutkami kryzysu gospodarczego? Czy w Polsce lewica może krzewić lewicowe hasła w gospodarce skoro czyni to największa partia prawicowa PiS?

Wyborcy z sympatią wspominający czasy przed 1989 r. głosują tylko na skrajną lewicę, pozostali o światopoglądzie lewicowym doceniają również zaangażowanie w reformowanie kraju. Oczywiście, w krótkim okresie czasu, takie zaangażowanie w reformy często prowadziło do przegranych wyborów np. SLD w Polsce w 1997 r., czy MSZP na Węgrzech w 1998 r., ale dawało szansę na powrót na scenę polityczną. Forsowanie pod płaszczykiem lewicowej solidarności pomysłów związanych z roz-

\footnotetext{
13 A. Krawczyk, Czechy: Komunizm wiecznie żywy, „Gazeta Wyborcza” z 5 lipca $2007 \mathrm{r}$

14 P. Bukalska, Ortodoksi, „Tygodnik Powszechny” z dnia 29 stycznia 2010 r.
} 
dawnictwem publicznych środków i prowadzących do załamania finansów państwa, już takiej szansy nie dawało. 17 września 2006 r. węgierskie radio ujawniło wypowiedź lewicowego premiera z zamkniętego spotkania jego partii. Tam w ostrych słowach przyznał się on do zakłamywania informacji o stanie węgierskiej gospodarki podczas kampanii wyborczej z kwietnia 2006 r., z czasów rządów jego i jego partii. Premier powiedział wówczas między innymi: „Kłamaliśmy rano, nocą i wieczorem. I wówczas, zresztą, nic nie robiliśmy w ciągu czterech lat. Nic. Nie możecie mi podać ani jednego poważnego efektu naszego rządzenia, z którego moglibyśmy być dumni. Nic. Kiedy trzeba będzie rozliczyć się z krajem, zapytają co robiliśmy w ciągu czterech lat, co odpowiemy? Nie ma wielu opcji. Nie ma, dlatego, że spieprzyliśmy. Nie tylko trochę, ale bardzo" ". Jeśli Fideszowi, zdecydowanemu zwycięzcy ostatnich wyborów na Węgrzech, uda się przywrócić stabilność gospodarczą odsunięcie socjalistów od władzy może być długotrwałe, a nawet skutkować rozbiciem tej partii.

Dobrym przykładem na wspomniane zagubienie programowe jest tutaj również nieistniejąca już słowacka Partia Demokratycznej Lewicy. Ugrupowanie to cieszyło się największym poparciem w początkowym okresie swojej działalności, gdy jej program niewiele różnił się od programu partii komunistycznej przed 1989 r. Późniejsza delikatna liberalizacja programu spowodowała odpływ wyborców twardogłowych, a nie zachęciła wyborców o bardziej liberalnych poglądach na gospodarkę. Partię pogrążyła ostatecznie ostatnia dramatyczna próba powrotu do początkowego wizerunku, gdy dokonano opisywanego już wcześniej odwołania reformatorsko nastawionej pani minister finansów. Miejsce po SDL' wypełniły zaraz radykalna Komunistyczna Partia Słowacji i Smer R. Fico.

Przykład czterech opisywanych partii pokazuje, że trzeba być albo zdecydowanie na lewo, albo blisko gospodarczego centrum. Znalezienie się gdzieś pomiędzy tymi biegunami prowadzi wcześniej czy później do klęski - nie da się być jednocześnie socjaldemokrata, liberałem i komunistą. Stopień tej lewicowości powinien być uzależniony od uwarunkowań politycznych i przede wszystkim otwartości na lewicowe hasła wyborców w każdym z państw. Ktoś może zapytać oczywiście co dalej jeżeli lewica nie różni się prawie od prawicy, czy ma przed sobą jakąś przyszłość? Być może będąca $\mathrm{w}$ defensywie lewica jest we współczesnym świecie przeżyt-

\footnotetext{
15 Całość na http://pl.wikipedia.org/wiki/Zamieszki_w_Budapeszcie_(2006), 1.04.2010.
} 
kiem? Być może świat poszedł już na tyle do przodu, że nie potrzebuje sztucznych podziałów na prawicę i lewicę? Być może, ale to już temat na zupełnie inny artykuł.

\section{Bibliografia}

Antoszewski A., Herbut R., Jednaka W., Partie i systemy partyjne w Polsce. Pierwsza faza przejścia ku demokracji, Wydawnictwo Uniwersytetu Wrocławskiego, Wrocław 1993.

Bukalska P., Ortodoksi, „Tygodnik Powszechny” z dnia 29 stycznia 2010 r.

Czarnecki K., Co po kryzysie polskiej lewicy, 25.06.2009, http://www.lewica.pl/?id=19622.

Galanova M., Czeskie fora dyskusyjne a Komunistyczna Partia Czech i Moraw: rozczarowanie i nostalgia za komunistyczna przeszłościq, http://www.cafebabel.pl/article/31834/nostalgia-za-komunistyczna-przeszloscia.html.

Grabiński T., Albo ona, albo my, „Gazeta Wyborcza” z dnia 24 stycznia 2002 r.

Kis J., Wegierska wojna domowa, „Gazeta Wyborcza” z dnia 8 marca 2008 r.

Kornai J., Stabilizacja i wzrost w procesie transformacji. Przypadek gospodarki węgierskiej, Wydawnictwo Akademii Ekonomicznej, Poznań 1998.

Krawczyk A., Czechy: Komunizm wiecznie żywy, „Gazeta Wyborcza” z 5 lipca 2007 r.

Pinior J., Rozpaczliwa agonia lewicy, „Dziennik” z dnia 27 marca 2009 r.

Sobolewska-Myślik K., Partie i systemy partyjne Europy Środkowej po 1989 roku, Księgarnia Akademicka, Wydawnictwo Naukowe, Kraków 1999.

Sobolewska-Myślik K., Partie i systemy partyjne na świecie, PWN, Warszawa 2006.

Sokół W., Żmigrodzki M., Systemy polityczne państw Europy Środkowej i Wschodniej, UMCS, Lublin 2005.

Sula P., System partyjny Republiki Węgierskiej, Wrocław 2005.

Systemy polityczne Europy Środkowej i Wschodniej. Perspektywa porównawcza, red. A. Antoszewski, Wydawnictwo Uniwersytetu Wrocławskiego, Wrocław 2006.

Szelegieniec P., Problemy z lewica, 25.03.2010, http:/lewica.pl/index.php?id=21264\& utm_source=feedburner\&utm_medium $=$ feed\&utm_campaign $=$ Feed $\% 3 \mathrm{~A}+$ politykawsieci+\%28Polityka+w+sieci\%29.

Wesołowski W., Partie: nieustanne kłopoty, Wydawnictwo IFIS PAN, Warszawa 2000. 


\section{Summary}

Political parties rooted in a non-democratic system have become a significant element of party systems in Poland, the Czech Republic and Hungary, where they have taken an active part in the transformation process. The paper assesses the significance of these types of groupings for the construction of a new democratic system by means of a comparison of four members of the Vysehrad Group. The ideological profiles of these parties and their position in the party arena are defined. Finally, an attempt is made to answer the question of how these groupings have adapted to the new democratic system, why some of them continue to play a crucial role in politics even today, while others are found somewhere on the outskirts of political life. The author's interests focus on the successors of those groupings that held full power before 1989: the Democratic Left Alliance in Poland, the Communist Party of Bohemia and Moravia in the Czech Republic, the Party of the Democratic Left in Slovakia, and the Hungarian Socialist Party. The example of the Communist Party of Bohemia and Moravia is of particular interest here as this is the only party that has not fundamentally changed its ideological profile and continues in isolation from other Czech groupings. At the same time, for twenty years, this same party has come third in the national elections, and even second in the European elections. 
